\title{
KÄÄNDEVORMIDE KASUTAMISE OSKUS EAKOHASE ARENGUGA VENE-EESTI KAKS- KEELSETEL NING SPETSIIFILISE KÕNEARENGU PUUDEGA ÜKSKEELSETEL LASTEL
}

\author{
Merit Hallap, Marika Padrik, Signe Raudik
}

Ülevaade. Artikkel otsib vastust küsimusele, kas ja mille poolest sarnaneb 5-6-aastaste eakohase arenguga vene-eesti kakskeelsete ja spetsiifilise kõnearengu puudega eesti ükskeelsete laste oskus kasutada käändevorme. Andmestik pärineb 101 lapse katsetulemustest eesti keele ainsuse käändevormide (v.a nominatiiv) ja mitmuse partitiivi moodustamisel. Selgitame, kas kakskeelsete ja kõnepuudega laste areng järgib eakohase arenguga ükskeelsete laste arengut. Vaatleme, milliseid vigu lapsed vormide moodustamisel teevad ning milliseid asendusvorme eeldatud käändevormide asemel kasutavad.

Võtmesõnad: lastekeel, keele omandamine, morfoloogia, kakskeelsus, keele ja kõne arengu patoloogia, eesti keel

\section{Sissejuhatus}

Eesti keele käändeparadigma on morfoloogilise süsteemi mahukas osa. Käändevormide kasutamise oskus annab väärtuslikku infot nii ükskeelse lapse kõnearengu kui ka kakskeelse lapse eesti keele oskuse taseme kohta. Samas on andmeid eesti keele käändevormide kasutamise kohta koolieelses eas vähe. Lastekeele uurijad on nüüdseks kirjeldanud peamiselt üksikjuhtumite näitel eesti keele grammatiliste vormide kujunemist spontaanses kõnes ükskeelsetel (vt nt Argus 2008, Lipp 1977, Salo 1994) ja sünnist saati kahte keelt omandavatel, nn simultaanselt kakskeelsetel lastel (eesti-inglise kakskeelsus vt Vihman 1982, soome-eesti vt Hassinen 2002). Nimetatud uurimustest ilmnevad mõned ühised tendentsid vormimoodustusoskuste kujunemisel: esimeste muutevormidena eelistatakse lõputa partitiivi ja lühikese illatiivi vormi, sisekohakäänete vorme hakatakse kasutama enne kui väliskohakäändeid, kohakäändevormidega väljendatakse enne siht- kui lähtekohta, varakult ilmuvad mitmuse nominatiivi ja partitiivi vormid, vormimoodustuse kujunemise 
algetappidel esinevad tüvevahelduse vead, morfeemid liituvad esmalt lühikestele, fonoloogiliselt lihtsatele tüvedele. Reili Argus (2008) kirjutab, et noomenivormide ilmumise järjekorda mõjutab muuhulgas muuttüübi produktiivsus ning lapse vajadus väljendada mingit semantilist rolli või suhet. Kõige olulisemaks peab Argus (2008: 42) aga sisendkeele mõju, millest oletatavasti (osaliselt) tulenevad ka juba mainitud uurimustes osalenud laste vormimoodustuse arengu erinevused.

Eesti keele käändevormide omandamise kohta on seega esmased andmed olemas ükskeelsete ja nn simultaanselt kakskeelsete laste osas. Koolieelses eas lastest moodustavad aga arvestatava osa ka nn astmelise kakskeelsusega lapsed (KK) ja spetsiifilise kõnearengu puudega lapsed (SKAP). Nende laste keelelise arengu uurimine ja hindamine on olulise väärtusega eesti keele õpetajate, lasteaiaõpetajate ning logopeedide jaoks. Samas Eestis praktiliselt puuduvad uuringud SKAP-laste ja kakskeelsete laste kõnearengu ja -profiili kohta. Spetsiifilise kõnearengu puudega laste oskust kasutada käändevorme on uuritud vaid üliõpilastööde raames (nt Heina 2011). Marika Padrik (2010) analüüsis doktoritöös SKAP-laste sõnamoodustusoskust. Eesti keele kui teise keele omandamist on käsitletud peamiselt täiskasvanud keeleõppijate näitel (nt Pool 2007). Ka keelekümblusprogrammi raames ${ }^{1}$ pole eesti keele kui teise keele omandamist koolieelses eas süsteemselt uuritud.

Et eakohase arenguga astmelise kakskeelsusega (KK-) ja ükskeelsete SKAPlaste keelelist arengut on Eestis vähe uuritud, on siinse uurimuse eesmärk selgitada, milline on eesti keele käändevormide kasutamise oskus vene-eesti kakskeelsetel ja spetsiifilise kõnearengu puudega eesti ükskeelsetel lastel. Alameesmärkideks on selgitada: 1) kas KK- ja SKAP-laste käändevormide kasutamise oskus sarnaneb eakohase arenguga ükskeelsete laste oskustele; 2) milliseid vigu teevad KK-ja SKAPlapsed käändevormide kasutamisel; 3) milliseid asendusvorme kasutavad KK- ja SKAP-rühmad käändevormide moodustamisel. Veatüüpide ja asenduste analüüs aitab otsustada, kas rühmade tulemuste vahel on kvalitatiivseid või kvantitatiivseid erinevusi.

\section{Spetsiifiline kõnearengu puue ja astmeline kakskeelsus}

Spetsiifiline kõnearengu puue (ingl $S L I=$ specific language impairment) $^{2}$ avaldub eripärase kõnearenguna. SKAP puhul ei esine muude arenguvaldkondade mahajäämust, st nendel lastel ei ole kuulmislangust, neuroloogilist ega kognitiivse arengu esmast kahjustust (Leonard 1998, 2009). Juba varases eas ilmneb märgatav kõnearengu mahajäämus: hilineb esimeste sõnade ilmumine ning mitmesõnaliste ütluste loome. SKAP-ile iseloomulikud vead kõnes muutuvad lapse arengu käigus: koolieelses eas avalduvad need eelkõige häälduses ja grammatikas, hiljem teksti tasandil ja kirjalikus kõnes (Kohnert 2008, Padrik 2006). SKAP diagnoositakse soovitavalt alles peale lapse nelja-aastaseks saamist, sest siis on juba võimalik hinnata, kas kõne areng on teiste laste omast erinev või mitte (Tomblin 2009: 424).

Ehkki arengu käigus on mõjutatud kõik kõneloome tasandid, peetakse SKAP-ile iseloomulikuks just grammatiliste oskuste puudulikku arengut (Kohnert jt 2009, Paradis 2010, Leonard 2009). Grammatiliste vigade põhjuseks on uurijate arvates

\footnotetext{
http://kke.meis.ee/keelekumblusest/teadusuuringud (25.9.13).

2 Termini spetsiifiline kõnearengu puue puhul on autorid lähtunud põhimõttest, et keele kui vahendi omandamisraskused avalduvad kõnes.
} 
kõnelise info töötluse probleemid, mistõttu on SKAP-lastel raskusi sisendkeele põhjal keeleliste üldistuste loomisega (Padrik 2010). Laste kõnes ilmnevad grammatilise tunnuse ärajätu, asendamise või lisamise vead. Et vead on keelespetsiifilised, võib eesti lastelt oodata eelnimetatutele lisaks $n$-ö morfofonoloogilisi vigu, mis avalduvad allomorfi vales valikus või moonutamises (Padrik 2006, Padrik 2010: 49).

Suuremates indoeuroopa keeltes on läbi viidud palju uurimusi selgitamaks, millised tunnused eristavad SKAP-laste kõnet eakohase arenguga laste kõnest. Inglise keelt kõnelevatele SKAP-lastele valmistab enim raskusi verbimorfoloogia: ajakategooria ja tegu- ning nimisõna ühildumine arvus (Kohnert 2008, Leonard 2009, Paradis 2005). Inglise keelest rikkama morfoloogiaga saksa keeles on SKAPlastele rasked nii verbi- kui noomenimorfoloogia (Dannenbauer 2001). Ungari (Lukács jt 2010) ja türgi (Rothweiler jt 2010) keeles teevad SKAP-lapsed rohkem vigu käändemorfoloogia kui verbivormide kasutamisel. Veel on andmeid, et nt hollandi keeles eksivad SKAP-lapsed enim sookategooria (Orgassa, Weerman 2008), hispaania keeles artiklite ja derivatsioonimorfeemide (Morgan jt 2013) kasutamisel. Võib teha esialgse järelduse, et rikka morfoloogiaga keeltes on SKAP-lastele noomenimorfoloogia verbimorfoloogiast keerukam.

Astmelise kakskeelsuse (ingl sequential bilingualism) puhul hakkab laps teist keelt (K2) omandama siis, kui esimeses keeles on saavutatud juba mingi taseme oskus. Astmelise ja simultaanse kakskeelsuse piir ei ole kindlalt fikseeritud. Johanne Paradisi (2010: 228) arvates on astmelise kakskeelsusega tegemist juhul, kui K2 hakatakse omandama peale 3-aastaseks saamist. Erineval arvamusel ollakse selles, kas kakskeelse lapse areng järgib ükskeelse arengut või mitte. Monika Rothweileri jt (2010: 542) järgi sarnaneb enne 3-4 aasta vanuseks saamist teist keelt omandama hakanud laste keeleline areng ükskeelsete arengule ja peale kuue aasta vanust täiskasvanud K2 omandajatele. Marilyn May Vihman ja Barry McLaughlin (1982: 54) märgivad, et kakskeelsete laste keelelise arengu mustrid võivad olla, aga ei pea olema sarnased esimese keele omandajate omadega.

Sarnaselt ükskeelsete SKAP-lastega on ka astmelise kakskeelsusega (edaspidi: kakskeelsete) laste keelelist arengut uurides täheldatud rohkete vigade esinemist keelelise arengu teatud etappidel. Uurijad (Paradis 2005, Orgassa, Weerman 2008, Kohnert 2008, Morgan jt 2013) on jõudnud järeldusele, et eakohase arenguga kakskeelsete laste vead morfosüntaktilisel tasandil sarnanevad ükskeelsete SKAP-laste vigadele. Paradis (2005: 179, 2010: 245) ja Kathryn Kohnert (2008: 95) märgivad, et kahe rühma sarnasus esineb morfoloogia varase arengu etapil, s.o peamiselt kahe esimese aasta jooksul kakskeelsetel lastel teise keele omandamise algusest ja SKAP-lastel grammatiliste morfeemide ilmumisest kõnesse. Kolmandal aastal võib juba täheldada erinevusi nende kahe rühma vahel.

Laurence B. Leonardi (2009) eri keeli kõnelevate SKAP-laste vigade analüüsist selgus, et keeliti võivad esineda eri tüüpi vead. Inglise ja itaalia keeles on täheldatud peamiselt morfeemide ärajättu kohustuslikust kontekstist, aga nt hispaania SKAPlapsed nii jätavad morfeeme ära kui ka asendavad neid. Paradis (2005) kirjeldas kakskeelsetel lastel sarnaseid veamustreid ükskeelsete SKAP-laste omadega, sh esines neil lastel rohkem morfeemi ärajätu- kui asendusvigu. Antje Orgassa ja Fred Weerman (2008) uurisid hollandi keele morfoloogiliste kategooriate kasutamist 7-aastastel ükskeelsetel, kakskeelsetel eakohase arenguga ja SKAP-lastel. Nende tulemused näitasid, et ükskeelsed SKAP- ja eakohase arenguga kakskeelsed lapsed 
tegid samu vigu mida nooremad eakohase arenguga ükskeelsed lapsed. Rühmade tulemused olid siiski kvantitatiivselt erinevad, sh sooritasid ükskeelsed SKAP-lapsed katse paremini kui kakskeelsed lapsed. Gareth P. Morgani jt (2013) uurimuse kohaselt jäi eakohase arenguga hispaania-inglise kakskeelsete laste tulemus hispaania ükskeelsete eakohase arenguga ja SKAP-laste tulemuste vahele: katsed paremini sooritanud kakskeelsed sarnanesid grammatilistelt oskustelt ükskeelsetele eakohase arenguga lastele ja halvemini sooritanud ükskeelsetele SKAP-lastele. Vigade analüüs näitas rühmades sarnaseid mustreid: ärajätuvigu oli rohkem kui asendusvigu.

Uurimuste tulemused on seega keeltest sõltuvalt erinevad. Teise keele omandajate ja SKAP-laste keelelise arengu sarnasus (teatud ajahetkel) raskendab nende markerite leidmist, mis eristaksid kõnepuudega kakskeelseid lapsi eakohase arenguga lastest. Just varase K2 omandamise etapi puhul on raske otsustada, kas tegemist on eakohase arenguga või kõnepuudega (Paradis 2005: 185). Enne, kui saab hinnata, kas kakskeelse lapse keeleline areng toimub oodatud viisil, on vaja andmeid selle kohta, mis on eripärane eakohase arenguga kakskeelse lapse arengus võrreldes ükskeelse lapse arenguga ning mis on iseloomulik kõnepuudega ükskeelse lapse keelelisele arengule. Et grammatilised oskused, sh vead on keelespetsiifilised, ei saa teiste keelte uurimuste järeldusi eesti keelele üle kanda.

\section{Katse ja informandid}

Uuringus kasutasime kohandatult Maarja Heina (2011) metoodikat käändevormide kasutamise oskuse uurimiseks. Katses tuli lastel moodustada 13 käändevormi (kõik käänded, v.a nominatiiv) ainsuses ja mitmuse partitiivi vorm. Viimane on erandlikult haaratud katsesse, sest on nii praktika kui ka Heina (2011: 32) uuringu alusel osutunud lastele üheks keerulisemaks vormiks oletatavasti käändetunnuse morfeemivariantide rohkuse tõttu. Et osa käändevormide kasutust uuriti erinevates funktsioonides (vt osa 4), oli laste ülesandeks moodustada kokku 21 vormi.

Keelematerjali valikul arvestati eesti keele spetsiifikat: tüve- ja lõpuvariantide varieeruvust ning käändevormide erinevaid funktsioone. Stiimulsõnad olid 1) lastele tuttavad, 2) nii suurema kui väiksema kasutussagedusega, 3) nii astmevahelduseta kui ka laadi-ja vältevahelduslikud, 4) piltide või reaalsete esemete abil näitlikustatavad. Näiteks genitiiv ja partitiiv tuli moodustada sõnadest põder, kringel, õis, aken, uks, kirss, lind, pliiats, jalg, saabas, padi ja täht. Nende vormide moodustamise ülesandes välditi sõnu, millel esineb vormihomonüümiat.

Meetodina kasutati vormikasutuse suunatud esilekutsumist (ingl structured elicitation method). Iga vormi puhul esitati lastele kaks näidist, et kindlustada ülesandest arusaamine. Lapsel tuli vastata uurija esitatud küsimusele ja/või lõpetada lause eeldatud sõnavormiga, toetudes esitatud piltidele või uurija poolt loodud mängulisele situatsioonile (tegutsemisele mänguasjadega).

Näiteks genitiivi (objekti funktsioonis) ning ainsuse ja mitmuse partitiivi vormide (hulgasõna laiendi funktsioonis) moodustamisel kommenteeris uurija mängukaru tegevust ja suunas last lauseid lõpetama: Vaata, mõmmil on lind (uurija osutab pildile). Mõmmi võtab veel ühe (osutab pildile) .... (linnu). Nüüd on mõmmil kaks (osutab kahele pildile) .... (lindu). Aga sïn (osutab pildile, kus on palju linde) on palju .... (linde). 
Kohakäänete kasutamisel koha, adressaadi ja lähteallika funktsioonis ning komitatiivi ja terminatiivi vormide kasutamisel pidi laps lõpetama uurija lause, toetudes küsimusele. Nt Kuhu ma palli panen? (uurija asetab palli korvi). Panen palli .... (korvi sisse/korvi); nt Milleni kiisu jookseb? (uurija imiteerib mänguasja liikumist objektini). Kiisu jookseb .... (aiani).

Ülejäänud vormide kasutuse uurimisel pidi laps lause lõpetama eeldatud vormiga pildi, lauselise konteksti (ja küsimuse) alusel. Nt Vaata pilti! Laual on puudu jalg (uurija osutab pildile). Laud on ilma .... (jalata); nt See on kass ja see on koer (uurija osutab mänguasjadele). Ütle kïsule, kellest ma räägin! Ta valvab maja. Ta elab kuudis. Kellest ma rääkisin? (uurija osutab koerale). Rääkisin .... (koerast).

Katse viidi läbi iga lapsega eraldi kahes jaos 2013. a kevadel. Testüksuste järjekord oli kõigil lastel sama. Järjekorra määramisel pidasime silmas, et 1) ühe või teise vormi kasutus ei mõjuta järgmise (sarnase funktsiooniga või sama vormi teise funktsiooniga) vormi kasutust (nt ei esitatud järjest allatiivi, adessiivi, ablatiivi), 2) suurema kasutussagedusega vormide (nt partitiiv) moodustamine vaheldub väiksema sagedusega (nt essiiv) vormide moodustamisega.

Valimi moodustasid 101 last. Lapsed jagunesid nelja rühma (vt tabel 1): 5-6-aastased eakohase arenguga vene-eesti kakskeelsed lapsed (KK), 4-6-aastased ükskeelsed SKAP-lapsed (SKAP) ning võrdlusrühmadena eakohase arenguga ükskeelsed 4-6-aastased (ÜK5-6) ning kolmeaastased lapsed (ÜK3). Kakskeelsete laste valikul arvestati järgmiste kriteeriumitega: 1) lapsed räägivad kodus ainult vene keelt, 2) lapsed käivad kolmandat õppeaastat eestikeelses lasteaias, 3) laste vaimne ja kõne areng on lasteaiaõpetajate ja logopeedide hinnangul eakohane. Tegemist oli seega lastega, kes hakkasid eesti keelt omandama kolmeaastaselt loomulikus suhtluskeskkonnas. SKAP-lapsed olid logopeedide poolt identifitseeritud kui kõnepuudega lapsed, kel ei esine muid arenguprobleeme.

Tabel 1. Katses osalenud lasterühmad

\begin{tabular}{|l|r|r|r|r|}
\hline Lasterühm & SKAP & KK & ÜK5-6 & ÜK3 \\
\hline Laste arv & 21 & 29 & 30 & 21 \\
\hline Vanusevahemik kuudes & $56-77$ & $61-80$ & $57-76$ & $32-39$ \\
\hline Keskmine vanus kuudes & 67 & 69 & 69 & 37 \\
\hline \multirow{2}{*}{ Sooline jaotuvus } & $\mathrm{N}=5$ & $\mathrm{~N}=16$ & $\mathrm{~N}=20$ & $\mathrm{~N}=11$ \\
& $\mathrm{M}=16$ & $\mathrm{M}=13$ & $\mathrm{M}=10$ & $\mathrm{M}=10$ \\
\hline
\end{tabular}

KK- ja SKAP-laste puhul püüti arvestada sellega, et nende laste grammatiliste oskuste areng oleks kestnud ajaliselt sama kaua. Lähtudes teadmisest, et SKAPlaste aktiivne morfoloogia omandamine algab tavaliselt kolme aasta vanuses (Dannenbauer 2001, Leonard 1998), valiti uuringusse KK-lapsed, kes olid eesti keelt hakanud omandama samuti kolmeaastaselt. Uurimuses kasutati võrdlusrühmadena 1) SKAP-ja KK-lastega ühevanuseid eakohase arenguga ükskeelseid lapsi (ÜK5-6), st uuritavatega potentsiaalselt sama vaimse arengu taseme ja suhtlemisoskustega lapsi; 2) nooremaid ükskeelseid lapsi (ÜK3), st uuritavatega potentsiaalselt sarnase keelelise arengu tasemega lapsi. 


\section{Tulemused}

Andmeid analüüsisime nii kvantitatiivselt kui ka kvalitatiivselt, kasutades andmetöötlusprogrammi STATISTICA 7.0. Kokku moodustasid lapsed 12928 sõnavormi, mida rühmitasime mitmel alusel: 1) õigete ja valede vastuste andmekogum; 2) vigadega moodustatud vormide rühmad. Õigeks lugesime vastuse, milles laps moodustas eeldatud vormi, kasutades seejuures ka õiget tüveallomorfi. Hääldusvigadest tingitud sõnade moonutusi tõlgendasime kahel viisil: 1) lugesime valesti hääldatud sõnavormi õigeks (nt hääliku ärajätt kaashäälikuühendist: kingit pro kringlit), kui oli võimalik määrata, mis vormi laps kasutas, või 2) märkisime moonutatud sõnana, kui vormi polnud võimalik ära tunda (nt ussus pro ust). Valed vastused jaotasime järgmisteks tüüpideks: 1) vale tüveallomorfi kasutus õige käändevormiga; 2) vale käändevormi kasutus õige tüveallomorfiga; 3) vale käändevormi kasutus vale tüveallomorfiga; 4) algvormi, s.o ainsuse nominatiivi kasutus eeldatud vormi asemel; 5) tõlgendamatu vorm sõnast või vastamata jätmine; 6) käändetunnuse vale morfeemivariandi kasutus (esines ainult mitmuse partitiivi puhul).

Esmalt pakkus meile huvi, kas KK- ja SKAP-laste käändevormide kasutamise oskuse areng järgib eakohase arenguga ükskeelsete laste arengut. Et võrrelda kõigi uuritud vormide kasutuse edukuse seost neljas lasterühmas, kasutasime Spearmani korrelatsioonanalüüsi. Õigete vastuste protsentuaalse osakaalu alusel vastuste koguarvust võrdlesime omavahel nii SKAP-ja KK-rühmade kui ka kummagi nimetatud rühma tulemusi ÜK3 ja ÜK5-6 tulemustega. Kõikide rühmade tulemuste vahel ilmnes tugev statistiliselt oluline korrelatsioon $(\rho=0,61-0,89, p<0,001)$, mis oli kõige tugevam KK ja SKAP ning nõrgem ÜK5-6 ja KK tulemuste vahel. Tulemustest järeldub, et kõikide rühmade puhul avaldus käändevormide kasutuse edukuses sarnane tendents: edukamad oldi samade vormide moodustamisel (nt allatiiv ja adessiiv koha tähistajana) ning raskusi valmistasid samuti samad vormid (nt essiiv oleku väljendajana, mitmuse partitiiv hulgasõna laiendina). Järgnevalt analüüsime täpsemalt vormide kasutust käänderühmade kaupa, püüdes leida nii kvantitatiivseid kui kvalitatiivseid erinevusi lasterühmade tulemuste vahel. Kvantitatiivses analüüsis kasutasime oluliste erinevuste leidmiseks korduvmõõtmistega dispersioonanalüüsi (ingl repeated measures ANOVA), kvalitatiivselt analüüsisime veatüüpe ja vormide asendusi. Dispersioonanalüüs näitas, et kõigi käändevormide puhul erinesid rühmad oluliselt vaid õigete vastuste alusel, veatüüpides ei olnud erinevused ühegi vormi puhul olulised.

\subsection{Grammatiliste käänete vormide kasutus}

Genitiivi vormide kasutamine osutus jõukohaseks ÜK3- ja ÜK5-6-lastele, kuid raskeks KK- ja SKAP-lastele. Genitiivi kasutamisel avaldusid rühmade tulemuste vahel olulised erinevused $(F(6 ; 95)=9,278 ; p<0,001)$. Post hoc analüüs Scheffé testiga kinnitas, et oluliselt erinesid õigete vastuste alusel KK- ja SKAP-lapsed ÜK3- ja ÜK5-6-lastest. SKAP- ja KK-laste tulemused, samuti ÜK3- ja ÜK5-6-laste tulemused olid õigete vastuste alusel sarnased. Vigade analüüsil ilmnes SKAP- ja KK-lastel sage algvormi kasutus genitiivi asemel. Kakskeelsed lapsed moodustasid genitiivi asemel paljudel juhtudel veel ainsuse partitiivi (nt võtab veel ühe ust pro 
$u k s e$ ), samas kui SKAP-lapsed kasutasid asendustes valdavalt mitmuse nominatiivi (nt võtab veel ühe uksed pro ukse).

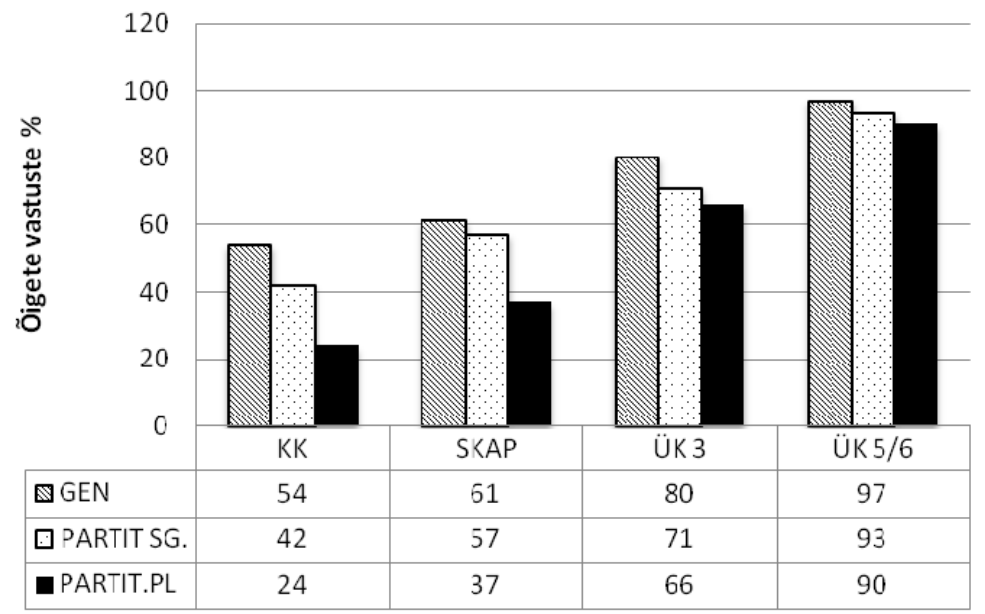

Joonis 1. Grammatiliste käänete vormide kasutuse tulemused

Ainsuse partitiivi kasutamine osutus kõigile lastele raskemaks kui genitiivi kasutamine. Dispersioonanalüüs näitas rühma kui faktori olulist mõju $(F(6 ; 95)=11,22$; $p<$ 0,001). Post hoc analüüsil selgus, et KK-laste edukus on oluliselt madalam kõigist teistest rühmadest. SKAP-laste tulemused olid sarnased ÜK3 tulemustega. Vaadeldes veatüüpide vahelisi proportsioone, selgus, et SKAP-lapsed kasutasid eeldatud vormi asemel palju algvormi, samas kui KK-lapsed moodustasid rohkem valesid vorme õige tüveallomorfiga (nt Mõmmil on nüüd kaks ukse pro ust) ja valesid vorme vale tüveallomorfiga (nt Mõmmil on nüüd kaks õised pro õit). Kahe rühma asendusvormid erinesid: SKAP-lapsed kasutasid ainsuse partitiivi asemel mitmuse partitiivi, KK-lapsed mitmuse nominatiivi ja ainsuse genitiivi vormi.

Mitmuse partitiiv osutus grammatilistest käänetest raskeimaks kõigile lastele. Dispersioonanalüüs näitas jällegi rühmade tulemuste vahel olulist erinevust $(F(6 ; 95)=11,38 ; p<0,001)$, post hoc analüüsi järgi ei olnud KK ja SKAP tulemused erinevad, küll aga erinesid mõlema rühma tulemused ÜK3 omadest. Vigade analüüsil ilmnes juba mainitud tendents: KK-lapsed moodustasid mitmuse partitiivi asemel teise vormi: peamiselt mitmuse nominatiivi (siin on palju linnud pro linde/ lindusid) ja ainsuse partitiivi (sïn on palju lindu pro linde). SKAP-lapsed eelistasid mitmuse partitiivi asemel ainsuse partitiivi. SKAP-lastel esines veatüüpidest kõige enam partitiivi tunnuse vale morfeemivariandi kasutust (nt siin on palju saapasid pro saapaid).

ÜK3-lapsed eksisid genitiivi kasutamisel tüveallomorfi ja partitiivi käändetunnuse morfeemivariandi valikul. Mõne teise vormi kasutust grammatiliste käänete asemel ÜK3-lastel ei täheldatud.

\subsection{Sisekohakäänete vormide kasutus}

Lapsed kasutasid illatiivi ja inessiivi vorme ainult koha funktsioonis, elatiivi lisaks materjali (on tehtud millest?) ja objekti (räägib kellest?) tähistajana. Vormide moodustamine koha ja materjali tähistamiseks osutus küllaltki jõukohaseks kõikidele 
rühmadele (vt joonised 2 ja 3). Elatiivi kasutamisel objekti märkijana eksisid SKAP ja KK kõrval küllaltki palju ka ÜK3-lapsed (vt joonis 3). Dispersioonanalüüs näitas sisekohakäänete vormide kasutamisel rühmade vahel olulisi erinevusi $(F(4 ; 97)=$ 6,3841; $p<0,001)$. Post hoc analüüsi kohaselt ei erinenud KK-ja SKAP-laste tulemused oluliselt vormide moodustamisel koha ja materjali tähistajana, küll aga olid KK tulemused oluliselt halvemad elatiivi kasutamisel objekti funktsioonis. SKAP rühm erines oluliselt ÜK3-st elatiivi moodustamisel materjali tähistajana, muudes funktsioonides vormide kasutamisel olid SKAP-laste tulemused sarnased ÜK3-le. KK tulemused olid sisekohakäänete kõigi funktsioonide puhul ÜK3-st oluliselt nõrgemad.

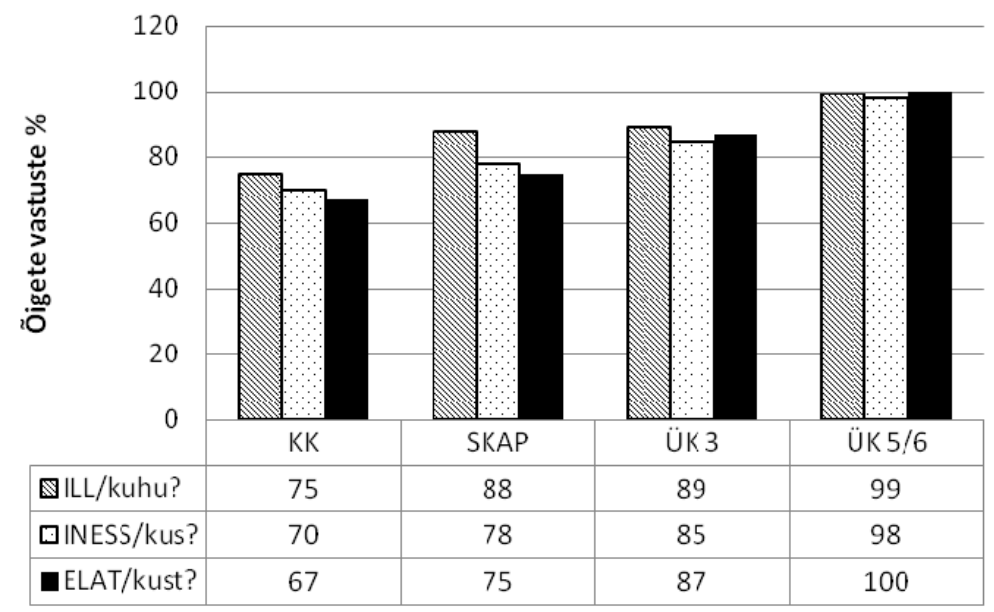

Joonis 2. Sisekohakäänete vormide kasutuse tulemused (kohta tähistav funktsioon)

Veatüüpide analüüsist selgus, et illatiivi moodustamisel kasutasid SKAP-lapsed küllaltki palju algvormi. KK-lapsed eksisid tüveallomorfi valikul ning moodustasid ka vale vormi (peamiselt allatiivi ja genitiivi). Inessiivi kasutamisel olid SKAP ja KK vead ühesugused: mõlemad kasutasid peamiselt valet tüveallomorfi. Elatiivi moodustamisel koha funktsioonis eksisid nii SKAP kui KK peamiselt tüveallomorfi valikul. Lisaks moodustasid mõlemad rühmad eeldatust erinevaid käändevorme, sh asendasid elatiivi peamiselt inessiivi vormiga (nt võtan palli taskus pro taskust). ÜK3-laste vead olid eranditult seotud vale tüveallomorfi kasutusega.

Elatiivi kasutamisel objekti tähistajana (vt joonis 3) said kõik rühmad sisekohakäänete vormide nõrgimad tulemused. Nii SKAP kui KK puhul oli eelkõige tegemist vale tüveallomorfi kasutusega. SKAP-lastel esines küllaltki palju ka algvormi kasutust. KK-ja SKAP-lapsed moodustasid ka teisi käändevorme, kusjuures kahe rühma vormiasendused olid erinevad: SKAP-lapsed kasutasid komitatiivi (räägib koeraga pro koerast) ja allatiivi (räägib koerale pro koerast), KK-lapsed aga ainsuse partitiivi ja ablatiivi (räägib koeralt pro koerast). ÜK3 vähene edukus tulenes taas vale tüveallomorfi kasutusest.

Elatiivi kasutus materjali tähistajana (vt joonis 3) valmistas SKAP-lastele pisut rohkem raskusi kui koha funktsioonis, KK-rühma tulemus oli nimetatud funktsioonide puhul sarnane. Tulemusi analüüsides ilmnes teistsugune tendents kui eelmiste vormidega: SKAP-lastel esines rohkem vale vormi moodustamist kui KK-lastel. Vormide asendused olid kahes rühmas erinevad: SKAP kasutas elatiivi asemel komitatiivi (on tehtud kummiga pro kummist), translatiivi (on tehtud paberiks 
pro paberist) ja inessiivi (on tehtud klaasis pro klaasist) vorme, KK inessiivi ja genitiivi. ÜK3-l esinesid üksikud tüveallomorfi vead.

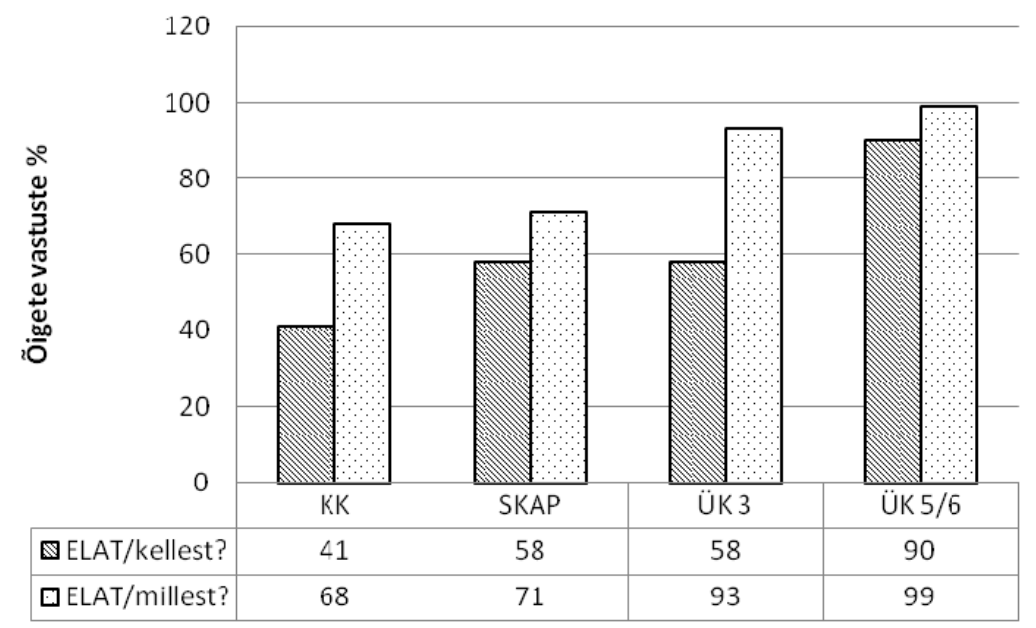

Joonis 3. Sisekohakäänete vormide kasutuse tulemused (objekti ja materjali tähistav funktsioon)

\subsection{Väliskohakäänete vormide kasutus}

Lapsed pidid allatiivi kasutama koha ja adressaadi (kingib kellele?), adessiivi koha, omaja (kellel?) ja aja ning ablatiivi koha ja lähteallika (sai kellelt?) tähistamiseks. ÜK5-6-lastele ei valmistanud raskusi ühegi vormi moodustamine (vt joonised 4 ja 5). Teiste laste tulemused sõltusid käändevormi funktsioonist.

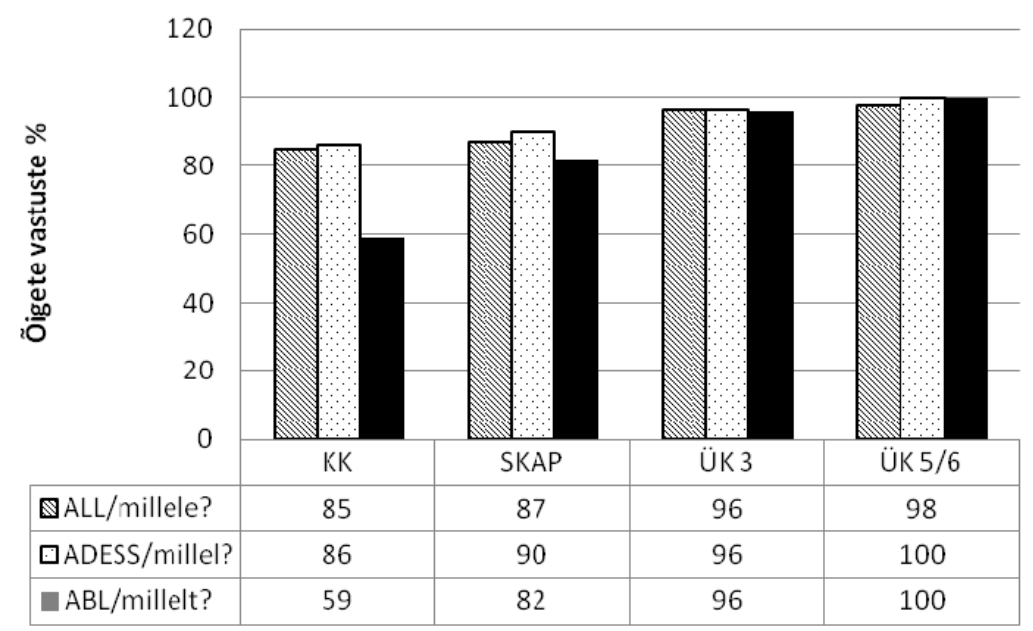

Joonis 4. Väliskohakäänete vormide kasutuse tulemused (kohta tähistav funktsioon)

Vormide kasutus kohafunktsioonis oli kerge kõigile, v.a KK-lapsed, kes olid raskustes ablatiivi moodustamisega. Oluliselt raskem oli KK-, SKAP- ja ÜK3-lastele adessiivi kasutamine omaja funktsioonis (kellel?) ja ablatiivi kasutamine lähteallika funktsioonis (sai kellelt?). Dispersioonanalüüs näitas rühmade tulemuste vahel statistiliselt olulist erinevust $(F(6 ; 96)=5,647 ; p<0,001)$. Post hoc analüüsil selgus, et KK tulemused olid SKAP omadest oluliselt nõrgemad ablatiivi moodustamisel 
kohafunktsioonis, muude vormide osas ei olnud erinevused olulised. KK-laste tulemused olid oluliselt nõrgemad ka ÜK3 tulemustest adessiivi ja ablatiivi kasutamisel kohafunktsioonis. SKAP-laste tulemused ei erinenud oluliselt ÜK3 omadest, v.a adessiivi kasutamisel aega tähistavas funktsioonis.

Vigade analüüsist selgus, et nii allatiivi kui adessiivi moodustamisel kohafunktsioonis oli KK- ja SKAP-lastel peamiseks veatüübiks vale tüveallomorfi kasutus. Ablatiivi puhul aga kasutasid mõlemad rühmad eeldatud vormi asemel muud käändevormi. Nii SKAP kui KK kasutasid kõige enam adessiivi (võtab vaibal pro vaibalt), sageduselt teisena esinenud asendusvorm oli SKAP-lastel genitiiv, KK-l elatiiv. ÜK3 nende vormide moodustamisel praktiliselt vigu ei teinud. Ka adessiivivormide kasutamisel omaja tähistajana eksisid KK- ja SKAP-rühmad ülekaalukalt tüveallomorfi valikul. SKAP-lapsed kasutasid küllaltki palju ka algvormi. ÜK3-lastel esinesid mõned tüveallomorfi vead. Aja väljendamine adessiivivormiga ei olnud raske ühelegi rühmale. Tegemist oli ilmselt tervikvormina omandatud sõnadega (nt talvel, hommikul).

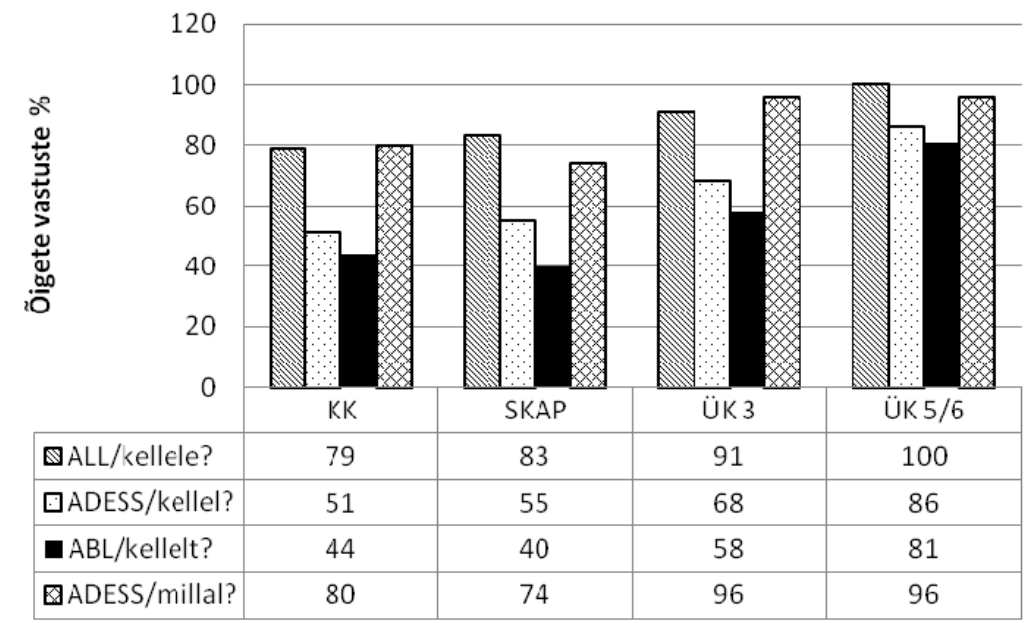

Joonis 5. Väliskohakäänete vormide kasutuse tulemused (adressaati, omajat, lähteallikat ja aega tähistav funktsioon)

Allatiivi moodustamisel adressaadi tähistamiseks eksisid KK-lapsed peamiselt tüveallomorfi valikul, SKAP-lastel esines nimetatu kõrval ka vale vormi kasutust peamiselt genitiivi. ÜK3-lapsed eksisid mõne üksiku tüveallomorfi valikul.

Väliskohakäänetest valmistas kõigile rühmadele enim raskusi ablatiivi kasutus lähteallika (sai kellelt?) märkimisel. Nii SKAP kui KK eksisid peamiselt tüveallomorfi valikul, aga ka valet vormi nii õige kui vale tüveallomorfiga esines küllaltki palju. Vormiasendused olid rühmadel sarnased: peamiselt kasutati elatiivi (sai kondi kassist pro kassilt), aga ka adessiivi (sai kondi kassil pro kassilt). ÜK3-lapsed eksisid ülekaalukalt ikka tüveallomorfi kasutamises, kuid esinesid ka üksikud valed vormid (elatiiv pro ablatiiv). 


\subsection{Muude käändevormide kasutus}

Translatiivi, terminatiivi ja essiivi kasutamisega tulid edukalt toime ÜK5-6-lapsed, teistele valmistas suuri raskusi essiivi moodustamine (vt joonis 6). Rühmadevahelised erinevused olid statistiliselt olulised $(F(2 ; 99)=22,244 ; p<0,001)$. Post hoc analüüs näitas, et KK-laste tulemused olid oluliselt madalamad SKAP omadest vaid terminatiivi moodustamisel. ÜK3-lastest oluliselt vähem kasutasid SKAP-lapsed õigesti translatiivi ning KK terminatiivi.

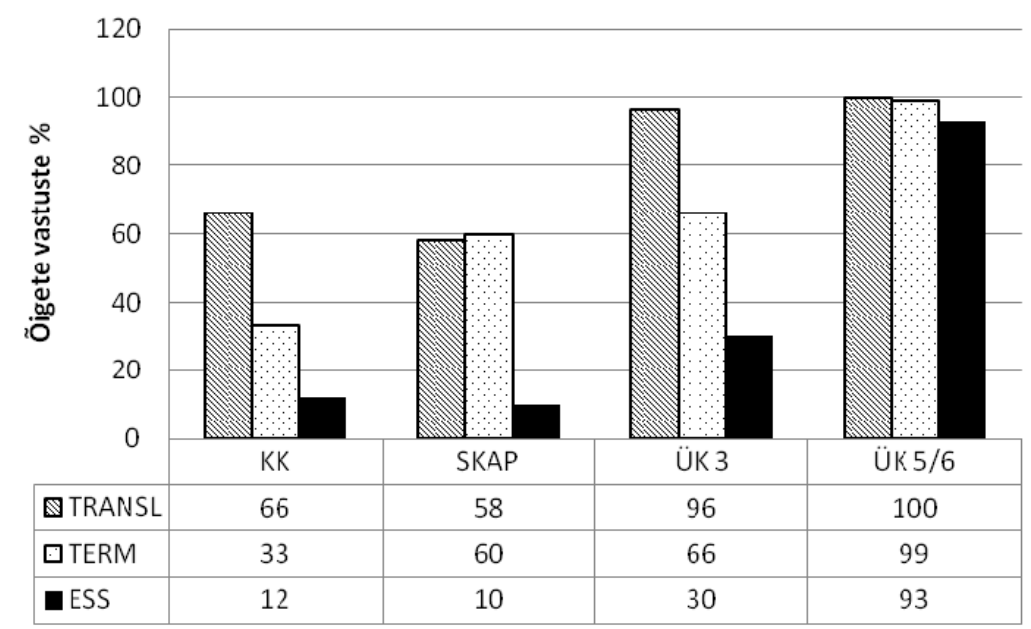

Joonis 6. Translatiivi, terminatiivi ja essiivi vormide kasutuse tulemused

Vigade analüüsil ilmnes, et translatiivi kasutamisel oli nii SKAP- kui KK-laste peamiseks veatüübiks vale vormi moodustamine. SKAP asendusvormid olid väga erinevad, st ei ilmnenud ühte kindlat asendusvormi, samas kui KK-lapsed kasutasid translatiivi asemel ülekaalukalt genitiivi (siil tahab ka saada lenduri pro lenduriks).

Terminatiivi puhul kasutas KK-rühm nii valet tüveallomorfi kui ka valet vormi õige ja ka vale tüveallomorfiga. Ka SKAP-lastel esines veatüüpidest enim vale vormi moodustamist, kuid SKAP ja KK asendused olid erinevad: SKAP-lapsed kasutasid peamiselt genitiivi ja KK allatiivivormi (nt jookseb munale pro munani).

Essiivi tulemused olid SKAP-, KK- ja ÜK3-lastel kõikidest vormidest nõrgimad. Kõigil oli peamiseks veatüübiks vale vormi kasutus õige tüveallomorfiga. Küllaltki palju esines ka algvormi kasutust, st sisuliselt kordasid lapsed uurija poolt öeldud lausest ametit märkivat sõna (nt See on eesel. Ta on lendur. Kellena eesel töötab? Eesel töötab .... lendur pro lendurina). Ühine kolmele rühmale oli allatiivi (töötab juuksurile pro juuksurina) ja komitatiivi (töötab juuksuriga pro juuksurina) moodustamine essiivi asemel. ÜK3-lastel olidki need ainsad asendusvormid. SKAPlapsed kasutasid aga erinevaid asendusi - peale eelnimetatute esines veel inessiivi, adessiivi ja elatiivi kasutust, KK-l enim translatiivi ja genitiivi.

Abessiivi ja komitatiivi kasutuse tulemustes ilmnes dispersioonanalüüsi järgi rühmade vaheline statistiliselt oluline erinevus $(F(2 ; 99)=11,74 ; p<0,001)$. Post hoc analüüs näitas ÜK5-6 tulemuste olulist erinevust teiste rühmade tulemustest; SKAP, KK ja ÜK3 tulemused olid sarnased. 


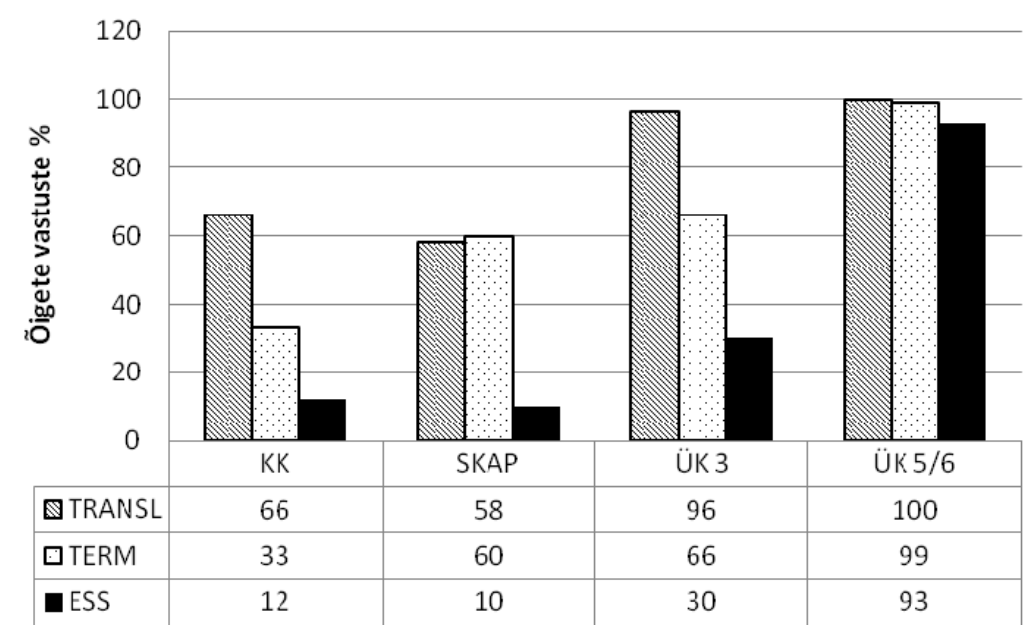

Joonis 7. Abessiivi ja komitatiivi vormide kasutuse tulemused

Abessiivi kasutuse edukus oli SKAP-, KK- ja ÜK3-rühmades küllaltki madal (vt joonis 7). Vigade analüüsist selgus, et nii SKAP- kui KK-lastel esines peamiselt vale vormi moodustamist õige või vale tüveallomorfiga. SKAP kasutas abessiivi asemel põhiliselt komitatiivi (maja on ilma aknaga pro aknata), KK ainsuse partitiivi ja genitiivi. ÜK3-lastel esines peamiselt vale tüveallomorfi kasutust, kuid täheldasime ka üksikuid vormiasendusi, sh kasutati eranditult komitatiivi.

Komitatiivi moodustamise suhteliselt madalad tulemused seostusid kõigil rühmadel vale tüveallomorfi kasutusega. Muid veatüüpe esines väga vähe.

\section{Arutelu ja kokkuvõte}

Püüdsime selgitada, kas ja kuidas sarnaneb KK- ja SKAP-laste käändevormide kasutamise oskuse areng ükskeelsete laste keelelise arenguga. Eeldatult kasutasid ÜK5-6-lapsed kõiki uuritud käändevorme peamiselt õigesti (õigete vastuste osakaal 78-100\%). ÜK3-lapsed erinesid mitmete käänete puhul edukuselt ÜK5-6-lastest, eksides valdavalt tüveallomorfi valikul, millele kui iseloomulikule veale vormimoodustuse kujunemise algetappidel viitab ka Argus (2008: 23). Võrreldes KK ja SKAP tulemusi kvantitatiivselt selgus, et enamiku käändevormide (v.a essiiv, translatiiv, ablatiiv lähteallika ning adessiiv aja funktsioonis) kasutamisel said madalamad tulemused KK-lapsed (õigete vastuste osakaal 12-86\%). SKAP-lapsed (õigeid vastuseid 10-90\%) paigutusid oma tulemustelt KK ja ÜK3 vahele, olles viimastest oluliselt nõrgemad genitiivi, mitmuse partitiivi, materjali tähistava elatiivi, aega tähistava adessiivi ning translatiivi osas. Kakskeelsete nõrgemaid tulemusi SKAP-lastega võrreldes täheldasid oma uurimuses ka Orgassa ja Weerman (2008). KK-laste tulemused olid SKAP omadest kvantitatiivselt oluliselt madalamad järgmistes vormides: ainsuse partitiiv, terminatiiv, elatiiv objekti ja ablatiiv kohta tähistavas funktsioonis. Samas oli mõnede vormide kasutamine nii KK- kui SKAP-lastele ka jõukohane (õigeid vastuseid üle 70\%; nt sise- ja väliskohakäänded siht- ja asukohta tähistavas funktsioonis, allatiiv adressaadi funktsioonis, samuti adessiiv aega tähistavas funktsioonis - viimase puhul on sõnad ilmselt omandatud valmisvormidena). Nimetatud käänete puhul mängib olulist rolli vormide 
kasutamissagedus, seega ka sisendkeele mõju, mille olulisust morfoloogiliste vormide ilmumise järjekorrale lapse kõnes on rõhutanud Argus (2008).

Oletust, et KK-ja SKAP-laste morfoloogiline areng järgib ÜK laste oma, kinnitab ka korrelatsioonanalüüs, mis näitas tugevat seost kõigi lasterühmade tulemuste vahel käänete järjestuses nende moodustamise edukuse alusel. Kvantitatiivse analüüsi alusel leidis seega kinnitust Paradisi (2005, 2010) ja Kohnerti (2008) seisukoht, et nende kahe lasterühma morfoloogia varane areng on sarnane. Samuti leiab toetust oletus, et KK-laste areng järgib ÜK-laste arengut, milles uurijad (Rothweiler 2010, Vihman, McLaughlin 1982) ei ole üksmeelel. Siiski ei saa teha ühest järeldust, analüüsimata laste vigu.

Nagu eespool mainitud, eksisid ÜK3-lapsed valdavalt tüve- või lõpuallomorfide kasutuses, st ilmnes lapse varasele grammatikale iseloomulik nn üleüldistamine. Võib oletada, et KK- ja SKAP-lapsed teevad samuti selliseid vigu (Lukács jt 2010, Leonard 2009). Olgu mainitud, et statistiliselt olulisi erinevusi veatüüpide sageduses SKAP- ja KK-lastel ei ilmnenud. SKAP ja KK vigade analüüsi alusel on võimalik välja tuua järgmist.

- $\quad$ Nii KK- kui SKAP-lastel esines sama tüüpi vigu: peamiselt vale tüveallomorfi (nt hobune kingib kaalika .... lammasele pro lambale) ja vale vormi (nt lammas sai kaalika .... hobusest pro hobuselt) kasutust, kusjuures nimetatud vead võisid samas sõnavormis ka kombineeruda (nt Aga siin on palju .... lindud pro linde/lindusid). Tulemused erinevad seega inglise keele baasil tehtutest, kus morfeemide ärajätuvigu esineb nii KK- kui ka SKAP-lastel rohkem kui asendusi (vt Paradis 2005: 182-183, Leonard 2009: 309).

- Käändevormide puhul, mille kasutuse edukus oli kõrgem ja mis ilmuvad lapse kõnesse varem (nt sisekohakäänded kohta tähistavas funktsioonis, komitatiiv), domineerisid mõlemal rühmal tüveallomorfi kasutusvead. N-ö raskemate käändevormide (translatiiv, terminatiiv, essiiv, abessiiv) puhul olid mõlemal rühmal ülekaalus vormide asendused.

- Enamasti asendati vorme sama käänderühma piires, näiteks grammatiliste käänete puhul asendasid SKAP-lapsed ainsuse partitiivi mitmusega, KK-lapsed kasutasid nii ainsuse kui mitmuse partitiivi asemel mitmuse nominatiivi (nt Aga siin on palju .... saapad pro saapaid). Kohakäänete puhul asendati vorme teise kohakäände vormiga (nt ablatiivi adessiiviga, elatiivi inessiiviga). Terminatiivi puhul esines mõlemal rühmal asendusi allatiiviga (nt Kiisu jookseb aiale pro aiani), st säilis käändevormi ruumi tähistav funktsioon. Ágnes Lukácsi jt (2010) andmetel on sellised lähedased asendused (ingl near miss errors) iseloomulikud SKAP-lastele rikka morfoloogiaga keeltes, st lapsed eksivad vormi moodustamisel vaid ühes tunnuses (nt arv, lähtekoht vs. asukoht). Niisiis võib väita, et SKAP- ja KK-lastel avalduvad käändemorfoloogia omandamisel sarnased vead, mis tulenevad omandatava keele eripärast.

- Asenduste analüüs võimaldab välja tuua ka erisusi SKAP- ja KK-laste vormikasutuses, mis avaldusid selgemini raskemate käänetega. Näiteks abessiivi asemel kasutasid SKAP-lapsed komitatiivi (laud on ilma jalaga pro jalata), mida võib selgitada asendusega tähenduse alusel (tunnuse olemasolu $v s$. puudumine), KK-lapsed aga genitiivi või partitiivi, mida võib selgitada vene keele mõjuga (без чего? $\rightarrow$ ilma jala; ilma jalga projalata). 
Elatiivi asemel (materjali funktsioonis) kasutasid SKAP-lapsed erinevalt KK-lastest komitatiivi (on tehtud kummiga pro kummist) ja translatiivi (on tehtud rauaks pro rauast), mis võib seostuda tegusõna piiratud tähendusega (valentsusega). KK-lapsed kasutasid elatiivi asemel sageli genitiivi, mis võib tuleneda n-ö tõlkimisest (tehtud из чего? $\rightarrow$ kummi pro kummist). Sama tendents avaldus elatiivi kasutamisel objekti tähistavas funktsioonis: SKAP-lapsed kasutasid komitatiivi või allatiivi (räägib koeraga/koerale pro koerast), KK-lapsed aga ablatiivi (räägib koeralt pro koerast, s.o tähenduselt lähedast vormi). Translatiivi puhul kasutasid SKAP-lapsed erinevaid asendusi, milles ei olnud võimalik tuvastada reeglipärasust. KK-lapsed kasutasid translatiivi asemel valdavalt genitiivi, mida võib põhjendada tegusõna tähenduse mittemõistmisega (tahab saada кого/kelle? $\rightarrow$ arsti pro kelleks? $\rightarrow$ arstiks). Sama käändevormiga esines SKAP-lastel ka moonutatud vormide kasutamist, mida ei esinenud kordagi KK-lastel.

- SKAP-lastele on KK-ga võrreldes iseloomulikum algvormi kasutamine, mis osutus peamiseks veatüübiks genitiivi, ainsuse partitiivi ja illatiivi puhul, kuid esines sageli ka elatiivi (räägib kellest?), adessiivi (kellel?) ja essiivi puhul. KK-l esines algvormi vaid genitiivi, translatiivi ja essiivi puhul.

Niisiis võib välja tuua erinevused SKAP- ja KK-laste asenduste tüüpides. SKAPlapsed kasutasid KK-lastega võrreldes sagedamini algvormi, nende asendused olid juhuslikud n-ö raskete käänete korral (nt translatiiv, essiiv), aga võisid tuleneda ka tegusõna piiratud tähendusest. Nimetatud eripära SKAP-laste vigade mustris on võimalik selgitada teistsuguse keele omandamise mehhanismiga (Padrik, 2010, Leonard 2009). SKAP-ile on omased süntagmaatiliste seoste piiratus, eriti tegusõna puhul (Dannenbauer 2001), raskused keele fonoloogilise süsteemi omandamisega (Padrik 2006, Dannenbauer 2001), mis põhjustab vormide häälduslikku moonutamist ja osaliselt ka algvormi või genitiivi kui häälduslikult lihtsamate vormide kasutamist. Viimast, samuti vormide ebapüsivat kasutust, on kirjeldanud ka Padrik (2010), Leonard (1998), Dannenbauer (2001). KK-lastel esines aga hulgaliselt asendusi, mida võib selgitada vene keele mõjuga. Võib oletada, et laps kasutab sobiva vormi leidmisel n-ö kodeerimist/tõlkimist vene keelest. Siiski ei ole alati võimalik vea põhjust üheselt selgitada: üheaegselt võivad mõju avaldada nii keeleline kui mitteverbaalne kontekst, teine keel või vormi häälduslik raskus.

Eeltoodud järelduste üldistamisel tuleb arvestada mitmete piirangutega. Et informantide rühmad olid väikesed, keskendusime kvalitatiivsele analüüsile, püüdes välja tuua tendentse, mida on vaja kontrollida suurema valimi baasil. Samuti võis tulemusi mõjutada keelematerjali valik: nt translatiivi ja essiivi puhul kasutatud elukutsete nimetused on häälduslikult rasked sõnad (õmbleja,juuksur, arst, lendur, ehitaja), sõnade arv ühe käändevormi kasutuse uurimisel oli paljude vormide puhul väike (4-5 sõna). Grammatiliste käändevormide kasutamisel esines nii SKAP- kui KK-lastel asendusi, mida võis selgitada katsematerjali mõjuga. Võib oletada, et eeldatud vormide kasutamise asemel kirjeldasid lapsed pildil kujutatut (nt eeldatud: võtab veel ühe põdra $\rightarrow$ laps: see on põder; eeldatud: palju põtru $\rightarrow$ laps: need on põdrad). On loomulik, et teist keelt omandav või alakõnega laps ei toetu ülesannet täites alati verbaalsele kontekstile, vaid vastab tajutavast situatsioonist lähtuvalt. Seetõttu oleks otstarbekas edaspidi nende vormide verbaalset konteksti muuta. 
Arvestama peab ka seda, et tulemused on saadud katsetingimustes, mistõttu vormikasutus võib erineda spontaanses kõnes esinevast. Seepärast tuleks meie uuringut käsitleda kui pilootuuringut esmase ülevaate saamiseks probleemist.

Uuringu põhjal selgus seega, et nii vene-eesti KK-lapsed, kes on eesti keelega kokku puutunud vähemalt kaks aastat, kui SKAP-lapsed järgivad käändemorfoloogia omandamisel ükskeelsete laste arengut. Olles käändevormide kasutamise edukuselt SKAP-lastest nõrgemad, sarnanesid KK-lapsed nendega vormikasutusvigade osas. Mõlemal rühmal esinesid valdavalt tüveallomorfivead ja vormide asendused; esines ka tunnuse ärajätte, mis oli siiski SKAP-lastele iseloomulikum veatüüp. Vigade analüüs võimaldas selgitada mõningaid käändevormide kasutuse kvalitatiivseid iseärasusi, mis vajavad kontrollimist edasiste uuringute käigus.

\section{Lühendid}

$\begin{array}{ll}\text { KK } & \text { astmelise kakskeelsusega laps } \\ \text { M } & \text { poiss } \\ \text { N } & \text { tüdruk } \\ \text { SKAP } & \text { spetsiifiline kõnearengu puue, spetsiifilise kõnearengu puudega laps } \\ \text { ÜK } & \text { eakohase arenguga ükskeelne laps } \\ \text { ÜK3 } & \text { eakohase arenguga ükskeelne kolmeaastane laps } \\ \text { ÜK5-6 } & \text { eakohase arenguga ükskeelne } 5 \text {-6-aastane laps }\end{array}$

\section{Viidatud kirjandus}

Argus, Reili 2008. Eesti keele muutemorfoloogia omandamine. [Acquisition of Morphology in Estonian.] Tallinna Ülikooli humanitaarteaduste dissertatsioonid 19. Tallinn: Tallinna Ülikooli Kirjastus.

Dannenbauer, Friedrich Michael 2001. Spezifische Sprachentwicklungsstörung. - Manfred Grohnfeldt (Hrsg.). Lehrbuch der Sprachheilpädagogik. Band 2. Stuttgart: Kohlhammer, 48-74.

Hassinen, Sirje 2002. Simultaaninen kaksikielisyys. Läheiset sukukielet viro ja suomi rinnakkain. Oulu: Oulu University Press. http://herkules.oulu.fi/isbn951426648X/ isbn951426648X.pdf (17.8.2013).

Heina, Maarja 2011. Käändevormide kasutamine ja mõistmine spetsiifilise kõnearengu puudega lastel. [Usage and Comprehension of Case Forms by Children with Specific Language Impairment.] Magistritöö. Tartu Ülikool. http://dspace.utlib.ee/dspace/ bitstream/handle/10062/23025/Heina_Maarja.pdf?sequence=1 (13.1.2013).

Keelekümbluskeskus. http://kke.meis.ee/keelekumblusest/teadusuuringud (25.9.2013).

Kohnert, Kathryn 2008. Language Disorders in Bilingual Children and Adults. Second printing. San Diego, Oxford: Plural Publishing.

Kohnert, Kathryn; Windsor, Jennifer; Ebert, Kerry Danahy 2009. Primary or "specific" language impairment and children learning a second language. - Brain and Language, 109 (2-3), 101-111. http://dx.doi.org/10.1016/j.bandl.2008.01.009

Leonard, Laurence B. 2009. Cross-linguistic studies of child language disorders. - Richard G. Schwartz (Ed.). Handbook of Child Language Disorders. Hove and New York: Psychology Press, 308-324.

Leonard, Laurence B. 1998. Children with Specific Language. Cambridge: A Bradford Book. Lipp, Ellen 1977. The acquisition of Estonian inflections. - Journal of Child Language, 4 (2), 313-319. http://dx.doi.org/10.1017/So305000900001689 
Lukács, Ágnes; Leonard, Laurence B.; Kas, Bence 2010. Use of noun morphology by children with language impairment: the case of Hungarian. - International Journal of Language and Communication Disorders, 45 (2), 145-161. http://dx.doi. org/10.3109/13682820902781060

Morgan, Gareth P.; Restrepo, M. Adelaida; Auza, Alejandra 2013. Comparison of Spanish morphology in monolingual and Spanish-English bilingual children with and without language impairment. - Bilingualism: Language and Cognition, 16 (3), 578-596. http://dx.doi.org/10.1017/S1366728912000697

Orgassa, Antje; Weerman, Fred 2008. Dutch gender in specific language impairment and second language acquisition. - Second Language Research, 24 (3), 333-364. http:// dx.doi.org/10.1177/0267658308090184

Padrik, Marika 2010. Word-Formation Skills in Estonian Children with Specific Language Impairment. Dissertationes pedagogicae Universitatis Tartuensis 8. Tartu: Tartu Ülikooli Kirjastus.

Padrik, Marika 2006. Milles seisneb kõnearengu puude spetsifilisus? [What is specific in language impairment?] - Eripedagoogika. Logopeedia ja emakeel, 26, 13-15.

Paradis, Johanne 2005. Grammatical morphology in children learning English as a second language: Implications of similarities with specific language impairment. - Language, Speech, and Hearing Services in Schools, 36 (July), 172-187. http://dx.doi. org/10.1044/0161-1461(2005/019)

Paradis, Johanne 2010. The interface between bilingual development and specific language impairment. - Applied Psycholinguistics, 31 (2), 227-252. http://dx.doi.org/10.1017/ So142716409990373

Pool, Raili 2007. Eesti keele teise keelena omandamise seaduspärasusi täis- ja osasihitise näitel. [The Acquisition of Total and Partial Objects by Learners of Estonian as a Second Language.] Dissertationes philologiae estonicae Universitatis Tartuensis 19. Tartu: Tartu Ülikooli Kirjastus.

Rothweiler, Monika; Chilla, Solveig; Babur, Ezel 2010. Specific language impairment in Turkish: Evidence from case morphology in Turkish-German successive bilinguals. - Clinical Linguistics and Phonetics, 24 (7), 540-555. http://dx.doi. org/10.3109/02699200903545328

Salo, Age 1994. Muutelõppude ilmumine ühe Eesti lapse keelde vanuses 1.5-2.5. [The emergence of inflectional endings in one Estonian child's speech, age 1;5-2;5.] - Jari Toivainen, Kirsti Toivainen (Toim.). Ensikielenä suomalaiskieli. Turun yliopiston suomalaisen ja yleisen kielitieteen laitoksen julkaisuja 46. Turku: Turun yliopisto, $22-28$.

Tomblin, J. Bruce 2009. Children with specific language impairment. - Edith L. Bavin (Ed.). The Cambridge Handbook of Child Language. Cambridge University Press, 417-431.

Vihman, Merilyn May 1982. The acquisition of morphology by a bilingual child: A whole-word approach. - Applied Psycholinguistics, 3 (2), 141-160. http://dx.doi.org/10.1017/ So142716400006676

Vihman, Merilyn May; Barry, McLaughlin 1982. Bilingualism and second language acquisition in preschool children. - Charles J. Brainerd, Michael Pressley (Eds.). Progress in Cognitive Development Research: Verbal Processes in Children. Berlin: Springer Verlag, 35-58. 
Merit Hallapi (Tartu Ülikool) uurimistöö valdkonnad on üks- ja kakskeelsete laste kõne areng ja kõnepuuded.

Näituse 2, 50409 Tartu, Estonia

merit.hallap@ut.ee

Marika Padriku (Tartu Ülikool) uurimistöö valdkonnad on kõnearengupuudega laste kõne areng ja arendamine.

Näituse 2, 50409 Tartu, Estonia

marika.padrik@ut.ee

Signe Raudiku (Tartu Ülikool) uurimistöö valdkonnad on kõnepuudega laste kõne areng ja arendamine.

Näituse 2, 50409 Tartu, Estonia

signe.raudik@ut.ee 


\title{
ESTONIAN CASE MORPHOLOGY IN SECOND LANGUAGE ACQUISITION AND SPECIFIC LANGUAGE IMPAIRMENT
}

\author{
Merit Hallap, Marika Padrik, Signe Raudik
}

University of Tartu

This paper presents findings from a study examining Estonian case morphology usage by typically developing Russian-Estonian sequential bilingual and monolingual Estonian speaking children with specific language impairment (SLI) aged 5-6. The control group included 5-6-year-old and 3-year-old monolingual typically developing Estonian children. Performance across groups was compared using the structured elicitation method. The findings suggest that children with SLI and typically developing bilingual children follow similar developmental paths in the early stages of grammatical acquisition. Moreover, the results reveal that the developmental patterns of both groups approximate those of monolingual Estonian language learners. Overall, the accuracy rates of case morphology production by bilingual children were lower than those of children with SLI. Both groups experienced more difficulties with the usage of the genitive, partitive, essive, terminative, abessive, and translative cases. The usage of locative grammatical cases (e.g. ablative, elative) in the secondary functions was limited as well. Both child groups basically made the same type of errors. However, qualitative analysis revealed that errors of omission of grammatical morphemes were more frequent in SLI children, while commission errors were more typical of bilingual children.

Keywords: child's speech, language acquisition, morphology, bilingualism, language and speech pathology, Estonian 